\title{
BIOASSEY IN THE MEDICAL TREATMENT OF THE INNER EAR DISEASES
}

\author{
T. MORIMITSU, M.D. I. MATSUMOTO, M.D. and K. HAYASHIDA, M.D. \\ Dept. of Otorhinolaryngology, Faculty of Medicine, Kyushu Univ. Fukuoka
}

(Director: K. Hiroto, M.D.)

\begin{abstract}
To make an assay whether or not a medicament has an actual value for bringing in the doubie blind test of inner ear dișeases, an experimental design was presented: 1. Recording of cochlear microphonics (CM) from the basal turn of the cochlea of guinea pigs, 2. Observation of the change in the amplitude of $\mathrm{CM}$ by applying $\mathrm{NaCl}$ crystals on the round window membrane 3. Observation of change of $\mathrm{CM}$ after applying both the medicament and Nacl crystals. 4. Statistical comparison of the resuls.

Meclophenoxate hydrochloride was used as a medicament in this study. This medicament had shown a significant effect in decreasing the $\mathrm{NaCl-effects} \mathrm{on} \mathrm{CM}$. It seems worthwhile to utilize Meclophenoxate hydrochloride for the double blind test in the inner ear disease.
\end{abstract}

A78-1271. 23555

\section{内耳疾患薬物療法の害験的根拠}

(特に Meclofenoxate hydrochloride について)

九州大学医学部耳鼻咽喉科教室 (主任 : 広戸幾一郎教授)

森満保 ·松元一郎・林田邦栏

\section{I 緒 言}

從来の内耳疾患薬物療法の最大の弱点は, 第一に使用 される薬物の内耳での作用をほとんど検討することな く, 他の臓器での作用と全く同じであろうと仮定して患 者に投与していたことであり，第二に対象となつた患者 の内耳疾患について，その病態なり病因をある仮定の上 に想定して試行錯誤的に治療を行つてきたことである 5. 仮定の上に仮定を組み合わせてその薬物の治療効果 を云々してみてもそこに得られる結果は極めて睖昧なる のであり次のステップへの足掛りにもならない低い価值 のものしか得られない. 例えば一般に血行改善剤とされ ているむのを内耳でむ血行改善作用ありとし，内耳血流 障害が本当に起つているか否か全く不明の患者に血流障 害があると腾手に決めつけて治療してきたところに今日 の内耳疾患薬物療法の混乱を招いた原因があつたと考光
る.

それでは内耳疾患の薬物療法の確固たる根拠はどらし たら得られるかていら設問に対しては残念ながら今なお 即答できない実状にある，そこでこうした問題をもう一 度反省してみるとともに最近耳鼻科額域でも広く用いら れている meclofenoxate hydrochloride を例に取って一 つの箺験を行ってみたのでその結果を報告する.

\section{II 薬物療法の実験的根拠について}

一般にある薬物が確加に内耳聅患化有効であると判定 するためには厳重な control 下での double blind test に よらなければならないし，この際に対象となる患者も厳 密に同一性翼の患者でなければならない, double blind test の理論は既に確立しているが，䈗密に同一性質の内 耳疾患患者を多数集めることは今日では不可能である し, 又全ての薬物についてこ 
を行らことむ不可能である。そこでまず double blind test 供するに足る薬物であるか否か，そしてその内耳 での作用はどのよらなものであるかを動物実験で screening することが必要となつてくる.

この実験的な screening を行う際にもいろいろのレべ

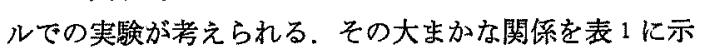
したが, 内耳血流, それも内耳動脈から一番末梢部と思 われる血管条やラセン血管のレベルまでの流量の増減を 問題にするか，これら末梢血管と内耳液の代謝（生産・ 吸収）のレベルを問題とするか，更にまた内耳液とラセ ン器有毛細胞の代铸（組織・呼吸）のレベルを問題とす るか少くとも 3 つのレベルが考えられる. 検討しょらと する薬物の性質からどのレベルでの検定を行らべきかも 充分に考慮し決めなければならない，

ここでもら一つ考えるべきことは，実験を正常動物の 正常な反応を指標にするか, あるいは何らかの負荷をか けて病的状態を作り出して実験を行らかといらことであ る.治療を目的とした薬効検定であれば当然病的状態で の検定でなければならないと思われるが，人工的に内耳 の病的状態を作りだすことは簡単なよらであるが，薬効 検定に役立つような病的状態を任意に高い再現性をもつ て作りだすことは極めて難かしい。

具体的に従来の知見に基づいて検誩してみると，第 1 のレベルである内耳血流に関しては螖牛開密下にその末 梢血管での血流を映画で観察する方法"1 と impedance plethysmography ${ }^{233)}$ による方法がある. 正常動物につ いてはかなり多くの報告があり，結論的には内耳血流は その母循環である渞循環とほぼ同じ薬理学的性格のもの といえる，しかし実際の臨床で予想されているような内 耳だけに限局した血流障害を実験的に作りだすことは極 めて困難なことで, 内耳動脈本幹を機械的に圧迫した り，微細な embolus を注入したりしての実験が実際の 患者のモデルとは到底考えられない 更に血流の増加が そのまま感覚細胞レベルでの治療的効果に直結しないこ とは明らかであり，内耳血流増加剤の中で最も強力な 5 $\% \mathrm{CO}_{2}$ 吸入が各種の内耳疾患患者で常に一定方向の治 療的効果を示さないことをわれわれは報告》している。

血管条を中心とした機能の動的観察には endocochlear DC potential (EP) が最む適当である. しかし正常のE P レベルを更に supernormal のレベルに高める薬物は ほとんどなく，僅かに $\mathrm{CO}_{2}$ 吸入時に一過性に認めるこ とか゚できただけである. normal の反応を supernormal にするか否かで治療効果を検定しょうとすることは非常
に危険な方法と考える.

EP を実験的に低下せしめるには5゙ anoxia にするか, 血流量を減少させるか, flocemide や ethacrinic acidな どと静注するか，極めて強大な音響負荷をする゙)などが あるが，こらした全身的な負荷によるE Pの低下では， その薬物効果は内耳での效果ではなくむしろ全身的な薬 物効果の検定とみるべきであるう.

内外リンパ液のレベルに関しては, Rauch tope を注入しての実験や，Na K電極を用いての実 験, ${ }^{8)}$ 更に Misrahy ${ }^{9)}$ らの内耳液 $\mathrm{O}_{2}$ 分圧測定の 実験 あり，特にこの $\mathrm{O}_{2}$ 分圧測定では既に小出 ${ }^{10)}$ らの薬効に 関する報告もある。

単に内耳血流量の増減のみならず，血管条の透過性ま でも含め内耳液の代謝レぶルでの検定としてこの $\mathrm{O}_{2}$ 分 圧測定ほ極めて有意義のむのといえるが，聴覚に関して はやはり閒接的な方法である.

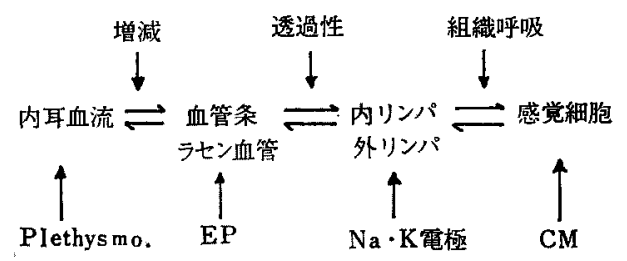

表 1 内耳での物質代謝と各レベルでの実験的指標

\section{III 実験指標としてのCMの意義}

内耳での最後のレふルとして cochlear microphonics （CM）を指標に実験を行う場合，その意義について若干 の検刢を加えてみたい。

CM は現在ではラセン器有毛細胞の activity を示す ものと理解されているが，この電位が聴覚の成立に関し て一次的な意義を持つものであるか，単なる二次的な epiphenomenon であるかについては未だ結論がでてい ないしたがってこの意味で $\mathrm{CM}$ を指標としてこれを聴 党イクオルと考えることは問題である.

しかしながら臨床的に内耳疾患患者治潦の指標として 用いられるものが聴覚しかない以上これに相対するる のとしてCMを用いることは合理的であるといえる.

$\mathrm{CM}$ を指標として薬物の效果検定を行抢うとする場合 の相互の関係を模式的に示してみると表 2 のよなるの が考えられる。

正常 $\mathrm{CM}$ について薬物を内耳局所に投与することによ つて内耳疾患の病因や病態生理の究明に重要な情報が得 られる。この際投与する薬物の作用が明確であればある 


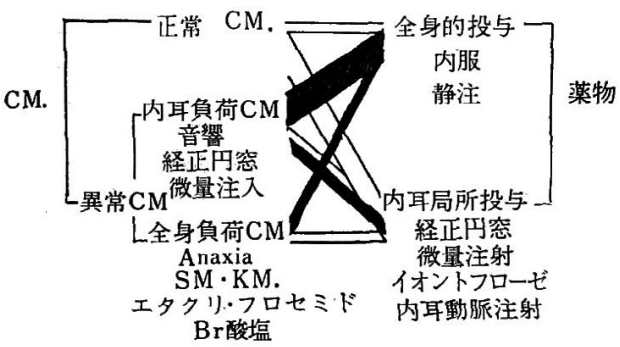

表 $2 \mathrm{CM}$ 指標とした薬物効果実験の模式図. 黒線は治療に関する情報を, 白線は病因 に関する情報を，太い程多く与えてくれ る.

ほどその意義は大となる，種々の条件を負荷して異常と なつた CMについて全身的に, 特に静注や内服で薬物を 投与することによつて主として内耳疾患の治療に役立つ 情報が得られる. 特に内耳局所に限局した負荷による異 常 CM 指標にすれば最も実際的な内耳疾患患者のため の情報が期待される．その他の組み合わせについてもそ れぞれ情報が期待されるわけであるが，それらを線の 太さと黒・白線で表現してみた。

内耳局所汇限局した負荷を与えることのできるもので 既知のものとしては強大音響負荷, 経螖牛空的薬物 投 与，および螖牛内一の直接的な microinjection などがあ る. 蝸牛の構造をできるだけ破壊せずに実験を行おらと 寸ればそれは経蝸牛空膜的な投与法に限られる。

この実験はCM が発見された直後の1953年 Hallpike ${ }^{11)}$ らと Davis ${ }^{12)}$ らの報告に始まり，その後多数の報告が見 られる。 その実験の目的は多くは CMの発生のメカニズ
ムの究明にあつた。われわれは1965年頃より同じよらな 経蝸牛空性薬物投与実験を, 蝸牛の部位別損傷に関する 研究の一環として differential electrode 法によつて行な いその結果を報告して ${ }^{18) 14}$ きた，その結果，正円空膜上 に一定量の $\mathrm{NaCl}$ 結晶を投与することによつて生ずる $\mathrm{C}$ Mの変化は, 内耳の血流, 血管条機能, 内外リンパ液代 謝そして毛細胞の activity までの全てプロセスの上に乗 つたものであり, 内耳の薬効検定の指標として従来の報 告にみない有意義な情報を与えてくれるものではないか との結論に達した. そこで具体的に meclofenoxate hydrochloride を用いて実験を行つたのでその結果を報告 する。

\section{IV 実験およびその成續}

実験方法：モルモットを用い基底回転より differential electrode 法を用いて $\mathrm{CM}$ を記録. 検查音は $\mathrm{CM}$ 出力 $300 \mu \mathrm{V}$ を得るに必要な強さの $300 \mathrm{~Hz}$ 純音を用い，持続 時間500msec, rise decay time $25 \mathrm{msec}$ の断続音を用い た. CM 記録法の詳細は既報に譲る.

まず control として分析篩を用いて大きさを平均0.23 $\mathrm{mm}$ 立方に揃えた $\mathrm{NaCl}$ 結晶 2 ケを螖牛空膜上に投与 ᄂ, 60 分間 $\mathrm{CM}$ 出力の変化を観察, 10 頭10耳の成䋶から 平均值と S D值を求める.

次に本実験として meclofenoxate hydrochloride 10 $\mathrm{mg} / \mathrm{kg}$ を静注し, 平均 5 分後に control と同様の $\mathrm{NaCl}$ 結晶投与を行ないCM 出力の変化を観察し，その結果を control と比較検討する.

実験成績：control および本実験の成績を図 1.2 .3 に 示した.

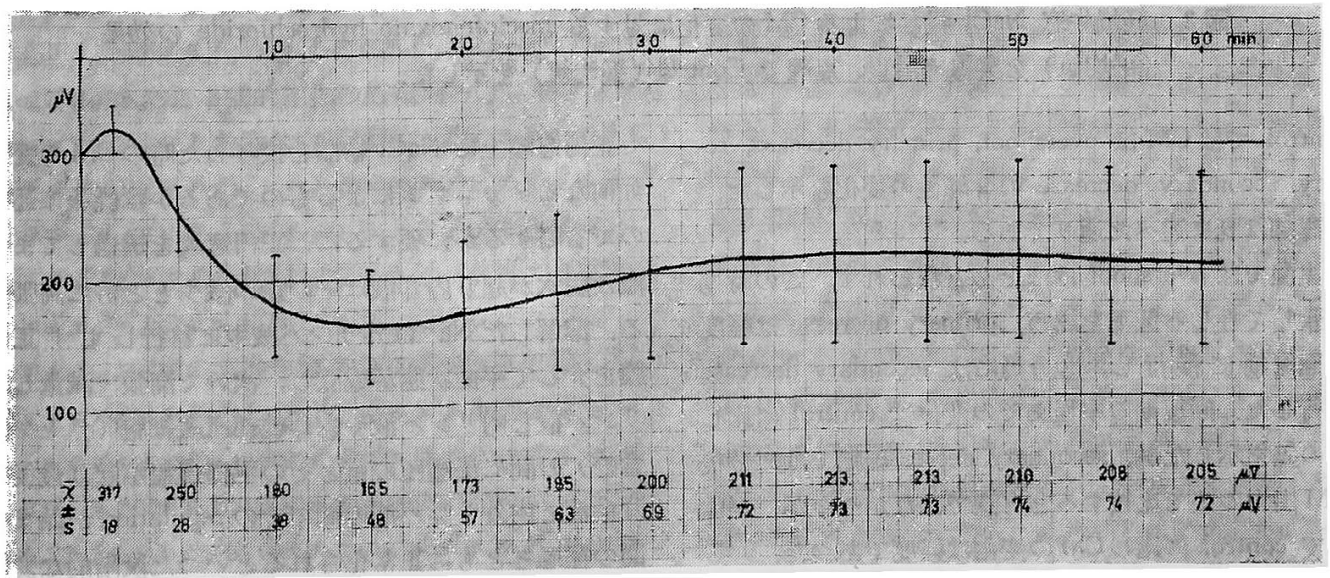

図 1 蝸牛空膜上 $\mathrm{NaCl}$ 結晶投与によるモルモット基底回転 $\mathrm{CM}$ の変化 


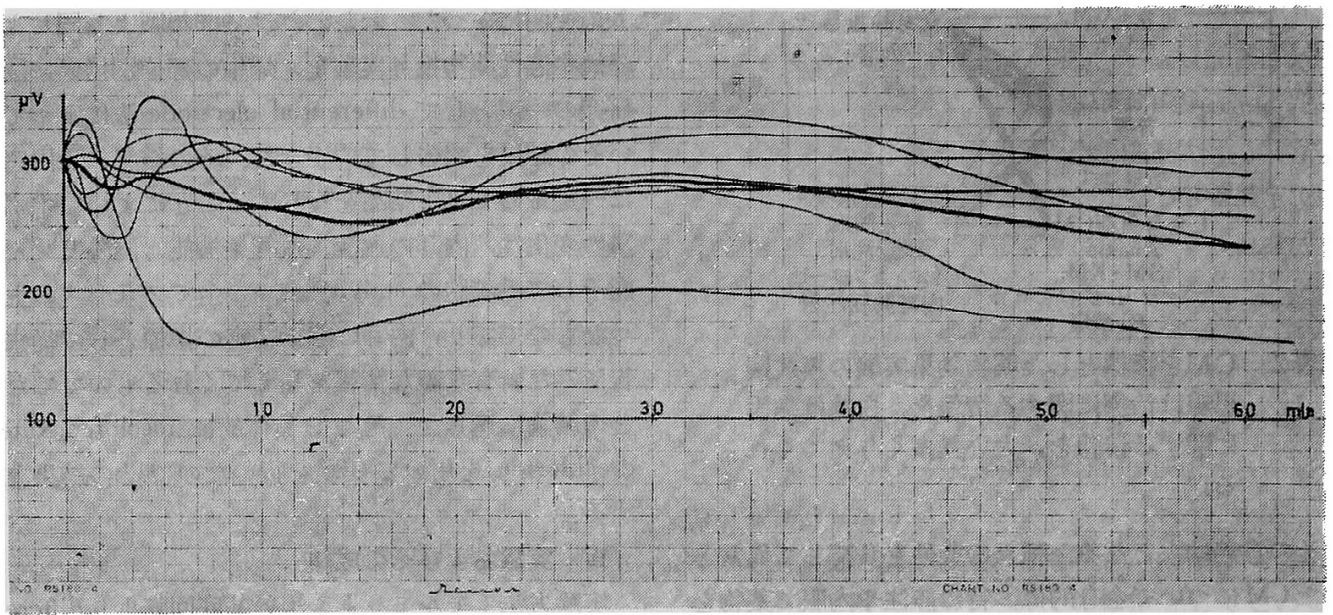

図 2 経蝸牛空 $\mathrm{NaCl}$ 投与による $\mathrm{CM}$ の変化に対する meclofenoxate hydrochloride の効果

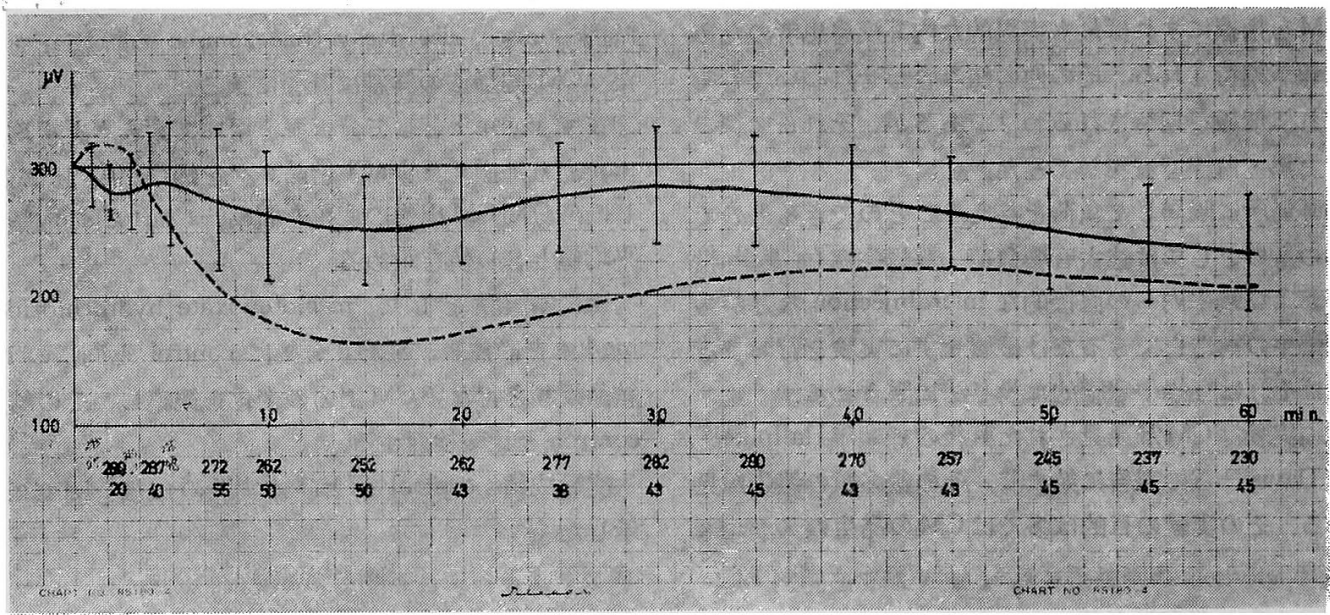

図 3 経蝸牛空 $\mathrm{NaCl}$ 投与による $\mathrm{CM}$ の変化に対する meclofenoxate hydrochloride の効果 (平均值) を実線で示し，点線で Control（平均値）を示した.

control では CM は overshoot, primary decrease, recovery, secondary decrease の 2 峰性の変化を示した. その詳細は既に述べた通りである。

本実験では overshoot はほとんど現われず，この時期 に一致してむしろ低下を認め, primary decrease は軽度 で，回復期に移行し，30分後には secondary decrease に移行した. 回復期の中程までの変化は control に比し 有意の差を示したが, secondary decrease 期では60分後 のCM出力の差で比較すると有意ではなかつたが，全体 として control に比し CMの変化は軽度であつた。

\section{$\mathrm{V}$ 実験成績の検討}

正円空膜上に $\mathrm{NaCl}$ 結晶を投与した時の $\mathrm{CM}$ の変化が 如何なるメカニズムによるものであるかは既報に述べた ので省略するが，要するに，正円空膜を透過してまず急 激な脱水が起り内耳液はその量の減少とともに高張とな る. 溶解した $\mathrm{Na}^{+}$は外リンパ液中に移行しまず正円空 膜を介して平衡状態が成立し，次いで高張・減量した外 リンパ液と内リンパ液や内耳軟部組織細胞（ラセン器も 含む）の間に浸透圧の差とその平衡過程が起り最後に内 耳血流と内外リンパ液の間でその regulation が始まり時 間の経過とともに正常化されるといつた段階的な変化か゚ 生ずる. MC の変化はこうした変化にそれぞれ対応して 


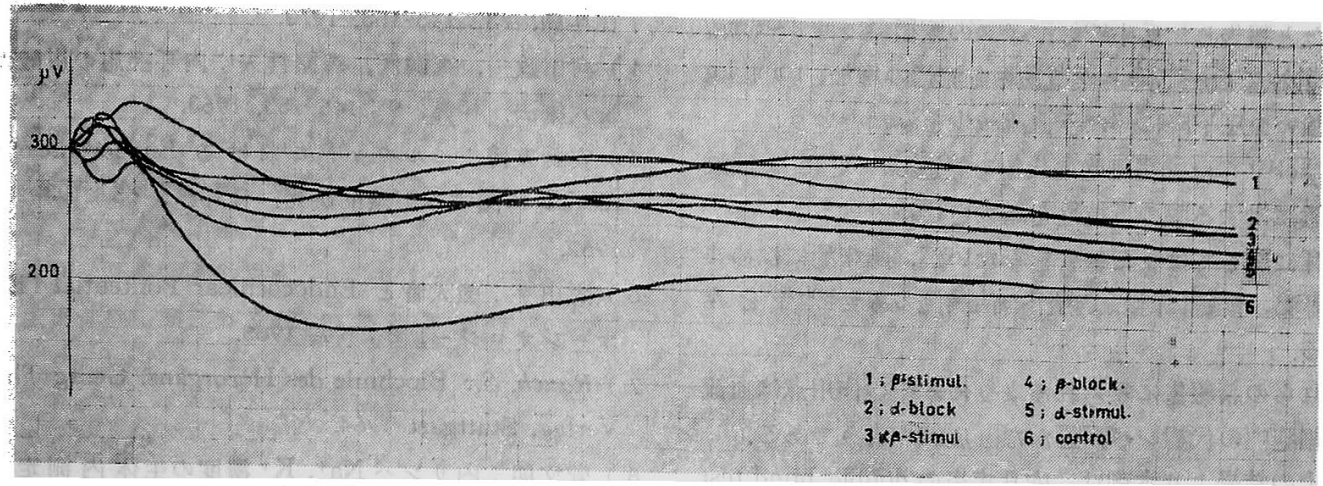

図 4 経蝸牛空 $\mathrm{NaCl}$ 投与による $\mathrm{MC}$ の変化に対する交感神経作用薬の効果

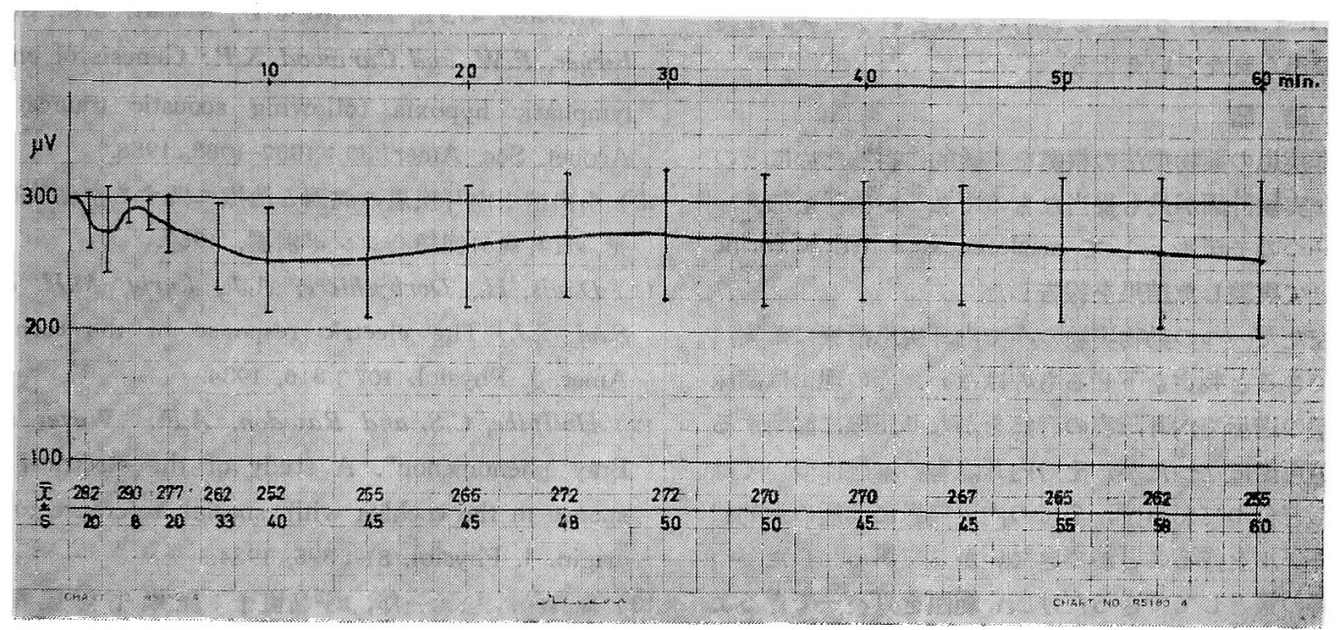

図 5 経蝸牛空 $\mathrm{NeCl}$ 投与による $\mathrm{CM}$ の変化に対する phenoxbenzamine の効果

$-\alpha$-clockade-

おり, overshoot 期から primary decrease 期は内耳液 を中心とした病的変化の進行期であり, recovery 期はそ の regulation による病的変化の修復期あり, secondary decrease はこうした急激な内耳環境の変化によつて生じ た有毛細胞の遅発性で，かつ irreversible な変性に基つ く低下を示していると理解される。こうした理解の上に 立つて本実験の成績を検討してみると, 本剤は内耳液の regulation control に比し促進しているといえる.

われわれは同様の実験を種々の交感神経作用薬を用い て行いその結果を報告した. ${ }^{142}$ 図4.5 にその成績を示し たが meclofenoxate hydrochloride は $\alpha$-receptor blockade である phenoxybenzamine に極めて類似した効果 を示しているといえる. $\alpha$-receptor blockade ナミンなどの $\alpha$-receptor stimulant による血管筋収縮作
用をブロックする作用を有しており柽度ながら血管拡張 作用もあるとされているが，これに結果的に類似した作 用を示したことは興味深い. 本実験に用いた負荷，すな わち $\mathrm{NaCl}$ 結晶投与による $\mathrm{CM}$ の変化は前述の通り内耳 液の代謝を中心に有毛細胞レベルでの変化を示すもので あり実験に用いた薬物が実際にどのレベルで作用したか は不明である．勿論，実験の結果が $\alpha$-receptor blockbde に類似した作用を示したからといつて，本剤がそのまま $\alpha$-receptor blockadeであるといらこともできない: 内耳 液の代謝が内耳血管を支配する交感神経によつて左右さ れることは理解できるが，本剤が血流に対していかに作 用するかはわれわれは知らない，ちなみに本剤の作用に 関する報告を紹介すると，脇坂 ${ }^{15)} ら は$ 脳創や脑内局所出 血に関する実験加ら, 大脳皮質, 視床下部の血流を増加 


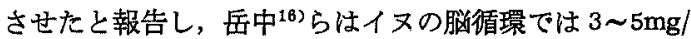
$\mathrm{kg}$ の静注で血圧下降と総頸動脈血流量の増加, $10 \mathrm{mg} / \mathrm{kg}$ では強い血圧下降に伴なう血流减少をみたという。

Nickel ${ }^{17)}$ らは神経細胞の代謝を促進し，更には低酸 素状態に対する脳の抵抗性を增大させるといら。

内耳に関してはまだ報告をみないが，臨床的にはめま い, 耳鳴, 難聴に対して若干の治験例の報告 ${ }^{18) ~ 22) ~ み ~}$ ている.

これらの諸報告にみられるように本剤の作用点は血流 量, 細胞内の代謝レベルとかなり広範のようである.

以上の結果より本剤は, 内耳疾患の double blind test に值する薬物であるか否かといら問題に対してはdouble blind test に供するに足る薬剤であるといら実験的な裹 うけは得られたといえよう。

VI 結 語

内耳疾患の薬物療法の根拠を実験的に得るためにどの ような実験計画が最む妥当なるのであるか検討を加え， その一つのモデルとして meclofenoxate hydrochloride を用いて実験した結果を報告した。

現在ただ一つの動物実験のみで内耳疾患治療に確実に 応用できると判定を下せるものはないその理由は臨床 耳科学の進歩で内耳障害の有無をかなり正確に診断する ことが可能になつたが，その内耳障害の本態については ほとんど分つておらず，全ての内耳疾患に共通の病的状 態のモデルを作ることができないからである．したがつ て次善の策としてできるだけ広い範囲をカバーできるよ らな実験条件を設定することに努力を集中すべきであ る. その目的に対して本報告に採用した内耳液の変化に 基つくく CMの変動を指標とすることはかなり合致したも のではないかと考える。

実験の結果から meclofenoxate hydrochloride は内耳 疾患治療の double bliind test に值する薬物ではない かと結論されたが，特に内耳液の代謝を促進することに よつてコルチ器の代謝改善を計ることが治療的勃果をも たらすのではないかと思われる疾患群に対して有効なの ではないかと思われる。

\section{文献}

1) Perlman, H.B., Tsunoo, M., and Spence, A.. Cochlear blood flow and functions; Effects of pressor agents. Acta Otolaryng. 51 ; 587-598, 1963.

2) 森满保: Impedance plethysmography K上る内耳

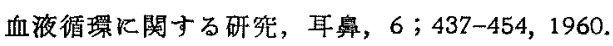

3）菅文朗：蝸牛血液得環飞対寸る血管桩張郕の効果,
日耳鼻，73；145-153，1970.

4) 河田政一, 森満保, 森囷哲夫：内耳疾患の炭酸ガス 吸入療法。耳番，9；146-153，1963.

5）安野友博：モルモットにおける Endoccchlear Poteotial 飞関する赛験的研究. 日耳番，65；193-219, 1962.

6) 志田亭：強大音々 Endocochlear Pontential (EP). オージオロジー, 8;1-7, 1965.

7) Rauch, S.: Bicchmie des Hororgans. Georg Thime Verlag. Stuttgart 1964.

8）菅文朗：内リンパ $\mathrm{Na}^{+}, \mathrm{K}^{+}$濃度の生体内測定. 日 耳睟， $73 ; 972-973,1970$.

9) Misrahy, G.H., Arnold, J.E., Mundi, J.R., Shinberger, E.W. and Carwood, K.P.: Genesis of endolymphatic hypoxia following acoustic trauma. J. Acouet. Soc. Amer. 30 ; 1082-1088, 1958.

10）小出靖：内耳疾患の成因と治療に関する生化学的研 枈。日耳貫61回総会シンポ別刷, 1959.

11) Davis, H., Derbyshiere, A.J., Lurie, M.H. and Saul, I.J.: The electric response of the cochlea. Amer, J. Physiol. 107 ; 316, 1934.

12) Hallpike, C.S. and Razudon, A.F.: "Wever and Bray phenomenon" A study of the electrical response in the cochlea with special reference to its origin. J. Physiol. 81 ; 395, 1934.

13）森満保，松元一郎，平島直子：経螖牛空膜投与 $\mathrm{NaCl}$ の Cochlear Microphonics に执よ注す影響につ いて, 耳舅, $18 ; 324-332,1972$,

14) 森渪保, 平島直子, 松元一郎: $\mathrm{NaCl}$ 蝸牛空膜投与 にょる Cochlear Microphonics の変化に対する交感神 経作用薬の影響，耳舅，19；20-30，1973.

15）脇双順一他：ルシドリールの脳㓣並びに譄内局所血 流に及ぼす影稗に関する実験的研觉。臨床と研究 $45 ; 620-623,1968$.

16）岳中典男他: Meclofenoxate (Lucidril) のイヌ脑循 環に扣よ至す影響。能本医学会雑誌，43；184-188， 1969.

17) Nickel et al.: Zur Wirkung von AminoaethanolDerivaten auf das Zentralnervensystem. ArzneimittelForschung $13 ; 881-883,1963$.

18）小田切醇他：耳舅咽喉科領域におけるルシドリール 錠の使用経験. 耳喉，41；139-143，1969.

19）坂田英治：メマイ・平衡障害飞怙ける眼球運動検查 
の診断的意美関する换討。診断々治療，58；505$516,1970$.

20）田精他：めまい症例に対する Lucidril の使用経験， 耳鼻臨床，66；943-957，1967.

21）桧学他：頭部外侮後遭淀に対するルシドリール使用 経験，特に大後磌神経ブロックに上る治療効果との比 䩙観察。耳鼻咽喉科臨床，60；841-857，1967.

22）上田伸他：頭部外傷後の愁挀に対する Centro- phenoxine の每注療法, 診療と新薬, 4;793-797, 1967.

本険文の要旨の一部恃第33回日本平衡神経科学会春季 学会, シンポ“めまいの薬物療法の根拠”で発表した。

（原稿受付 眧和49.9.25日） 